\title{
FAULKNER'S ALPINE APPRENTICESHIP: "MISTRAL" AND "SNOW"
}

\section{Michael Orlofsky}

MANY CRITICS HAVE been intrigued by William Faulkner's maturation as a novelist during the years 1925 to 1929. Some observers have labeled his development a "quantum leap from appprenticeship to mastery" (Broughton), others have explained it as a capacity finally to "judge his region and sometimes even quarrel with it" (Tate cited by Brooks), and Faulkner himself attributed it "to a new disregard for the marketplace." ${ }^{1}$ But it would seem - rather than a quantum leap - that Faulkner's development was gradual and methodical from his New Orleans Sketches and "third-rate poetry" to the more sophisticated themes, characters, and plotting of Flags in the Dust/Sartoris and the stylistic and narrative bravado of The Sound and the Fury. ${ }^{2}$

Faulkner commented that The Sound and the Fury started as a short story, which "still wasn't enough," so he wrote three more versions of the story about "the tragedy of two lost women," which were still "not enough." He had to admit that he "never could tell it right."3 Through information that came to light from the discovery in 1970 of two "lost" introductions that Faulkner planned to include with a new edition of The Sound and the Fury (an edition that was never published), Broughton says that the "break between the apprenticeship of Flags in the Dust/Sartoris and The Sound and the Fury apparently perplexed Faulkner as much as it does us" (p. 63). However, it would appear that in his early short stories Faulkner discovered, refined, and experimented with the characters and techniques that later were more fully explored in his novels. After all, Faulkner complained with some rue to Joan Williams that he had been writing stories for ten years before an editor decided to purchase one ("A Rose for Emily," in Forum, April 1930). " Increasingly, the early stories are attracting critical attention as Faulkner's first forays into his nascent fictional world.

Two characters who play important roles in Faulkner's most respected novels are Shreve McCannon and Quentin Compson; these characters may have had their prototypes in Don and the " $\mathrm{I}$ " narrator of four early stories. 
These stores are "The Big Shot," "Evangeline," "Mistral," and "Snow."' They are fertile territory. Joseph Blotner, for example, discerns the characters Popeye, Temple Drake, Thomas Sutpen, Wash Jones, Flem Snopes, and even Gail Hightower in "The Big Shot" (Uncollected, p. 707). It is obvious that "Evangeline" introduced the characters and plot that would evolve into Absalom, Absalom! Both Blotner and J. Wittenberg in Atlantic have elaborated on the relationship between the two works. But "Mistral," and "Snow" in particular, have been glossed over by critics as stories in which Faulkner formulated themes, characters, and techniques that he would employ throughout his career.

"Mistral" first appeared in These 13 in 1931, but it had been written a few years earlier; "Snow" never appeared in Faulkner's lifetime, and in fact wasn't pubished until 1979. But it, too, probably had been written early in Faulkner's career-although the first record of its existence is in Harold Ober's (Faulkner's agent) files on February 17, 1942.

Faulkner's financial straits are legendary, and the suspicion arises that to appease some of his debtors he dredged up old stories, revised them, and submitted them with the hope that his reputation might persuade editors to buy. This may have been the situation with "Snow" in 1942. Also, Faulkner by nature revised and rewrote extensively, changing person, tense, and point of view in efforts to relate his narratives as effectively as possible. Blotner feels that Faulkner usually wrote his stories soon after the time they describe. Although the opening paragraphs of "Snow" are told through a third-person narrator during the eary 1940s, the bulk of the story is narrated in the first person and takes place fifteen years before the opening scene. That time frame roughly corresponds to the walking tour of Italy, Switzerland, and France that Faulkner and William Spratling took together between July and December 1925. Both "Mistral" and "Snow" take place in Europe - the former in the Italian Alps, the latter in the Swiss-and both Don and the "I" narrator are in their mid-twenties.

The question of why the stories are set in Europe has two relatively easy answers: first, as young authors are wont to do, Faulkner presented settings that he thought had inherent drama and romance (one need only recall the acclaim another young American writer had been receiving in the late 1920s for his fiction set in Paris, Milan, and Pamplona); second, setting normally is subordinate to matters of characterization, plot, and theme. Not until Faulkner realized Sherwood Anderson's advice to him that he was a "country boy; all you know is that little patch up there in Mississippi where you started from," did his setting, characters, and themes settle into that nothern Mississippi piedmont. ${ }^{6}$ Still, they were the mysteries of the human heart in conflict with itself that Faulkner was exploring in "Mistral" and "Snow."

"Mistral" gets its title from the strong wind blowing off the Mediterranean during fall and winter. The story takes place in the mountains north of Milan, and as the events progress through afternoon to late evening, the 
mistral picks up, becoming for Faulkner symbolic of evil as revealed to two Americans by the details they learn about a local priest and his female ward. The mistral envelops Don and the narrator that evening and casts a vortexlike agitation over scenes and events. The story begins as the youths encounter a gruff soldier pushing a bike; he passes quickly and soon the Americans meet a signor and signora sitting at a roadside shrine. A conversation develops, and the youths are told that a funeral will take place that day in the next village. The man to be buried died suddenly and was the rich fiancé of the priest's ward. It should be noted here that a plot device appears at the beginning of "Mistral" which was to become a standard Faulknerian technique-christening his narrative with either a death or a funeral. "A Rose for Emily" and The Sound and the Fury open with funerals, while Light in August, "Carcassone," and "Snow" start with a death, a death that the plotting endeavors to reconstruct. Blotner views it as a technique of "withholding information and working by implication rather than statement." This reconstruction or "withholding" of events ending in death reaches its greatest convoluted depths, of course, in Light in August and Absalom, Absalom! It seems apparent that for works as complex as these, Faulkner pursued a long apprenticeship that began many years earlier with tales like "Mistral."

The signora in the story requires little inducing from Don to fill in the particulars leading up to the funeral. The priest's ward (Faulkner never gives her a name) had a lover-Giulio-before her betrothal had been arranged with the rich young man, but she had successfully postponed her wedding for three years. By what the signora calls "the hand of God" (p. 849), Giulio was called into the army. It was he with the bike that the Americans encountered in the opening passage of the story. Ironically, Giulio was visiting the village to act as one of the pallbearers at the fiancé's funeral. However, the signor then repeats what obviously had been a standing rumor in the village: "The priest looked at her, too. . . . For a man is a man, even under a cassock" (p. 850). The signor used "looked" as a euphemism for "lusted." The signora already had suggested that the Americans might find shelter or food with the priest, and after the gossip about him, his ward, and her suitors, the Americans make it a point to try to find the rectory. The travelers leave the couple and head into the village; almost on cue, as they enter it "the wind. The wind began as soon as the sun went down ... a steady moving wall of air full of invisible particles of something" (pp. 852-53).

As the Americans assemble more details of the priest's complicity in the fiancé's death, the mistral gusts more and more forcefully. It is an elemental image that Faulkner incorporates to display his protagonists' growing awareness of evil. In the denouement, Don and the narrator realize that the priest is responsible and damned for the death of the fiancé because of his jealousy for his ward. This realization of evil (and their own loss of innocence by comprehending it) parallels the strongest description of the mistral given in the story: 
That damn wind. That damn wind. . . I I could see past my shoulder his [Don's] cigarette shredding away in fiery streamers upon the unimpeded rush of the mistral, that black chill wind full of dust like sparks of ice. (p. 876)

The intensificaton of elemental symbols juxtaposed to characters' heightening concern with and acknowledgement of evil later attains a haunting power in Absalom, Absalom! In their dorm at Cambridge, as Shreve and Quentin gradually come to a better understanding of Thomas Sutpen's failure to perceive the humanity of those closest to him, the room becomes increasingly colder. One wonders if Shreve had Dante in mind when he used the apposition "that demon" in reference to Sutpen. Just as Dante has the Devil embedded in ice in the ninth circle, so too, "At first, in bed in the dark, it seemed colder than ever, as if ... the iron and impregnable dark had become one with the iron and icelike bed clothing" (p. 360). Absalom, Absalom! concludes with an elemental metaphor equal in strength to the wind in "Mistral;" Quentin is distraught thinking about himself, Sutpen, and the South and is "panting in the cold air, the iron New England dark" (p. 378). It seems likely, then, that Faulkner had been practicing his dramatic, imagistic endings in his earlier stories.

But it is not only imagery and plotting that are foreshadowed in "Mistral"-themes also receive a degree of formalization. In particular, there is that enigmatic circumstance that is not precisely unrequited love-rather, a relationship that is doomed from its inception. And, of course, there is the matter of incest. When the Americans enter the village, they watch the funeral, then follow it into the church because of "the harsh green twilight (the air was like having to drink iced lemonade in the winter time)" (p. 857). During the service, Don tells the narrator in extemporaneous whisperings his conception of the torment the priest may have suffered living with his ward, the daughter of a Milanese prostitute:

\footnotetext{
"He had to sit across the table from her, say, and watch her. Watch her eating the food that made her change from nothing and become everything, knowing she had no food of her own and that it was his food that was doing it, and not for him changing. You know girls: girls: they are nothing, then they are everything. You watch them become every thing before your eyes. No, not eyes: it's not their becoming everything that you dread: it's their finding it out after you have long known it: you die too many times. And that's not right. Not fair. I hope I'll never have a daughter."

"That's incest," I whispered. (p. 858)
}

Loss ("little sister death") and incest are obsessive themes in The Sound and the Fury and Absalom, Absalom!, and although they may be traced back in Faulkner to his desire to have a sister or his close relationship with his mother, a less psychoanalytical explanation can be found in his literary inheritance. Prior to his sojourn in New Orleans and his tour of Europe, Faulkner derived much of his poetic and fictive impetus from the English Romatics, Swinburne, Wilde, Mallarmé, Yeats, and even the Art Nouveau illustrator Beardsley. Cleanth Brooks states that similarities exist between 
their work and Faulkner's verse, drama, and early prose (particularly "Nympholepsy," The Marionettes, and Mayday). One of the strongest ties among them is their yearning to preserve "something unattainable." Brooks cites the nineteenth century writers as examples to establish Faulkner's foundation in the romantic tradition, and contends that he "began as a romantic, and a romantic he remained to the end, though a reformed or foiled or chastened romantic" (Toward Yoknapatawpha, p. 51).

The holding power of romanticism on Faulkner reinforces the position that his earliest concerns remained with him, albeit transformed to one degree or another, through his life; it also highlights the suggestion that his early years were the matrix in which he formed his literary stance. Broughton notices a similar incremental development beginning about 1925:

New Orleans seems to have not only released Faulkner from a number of psychic bonds, but it also released him from a number of literary bonds because there he was thoroughly exposed to modernism for the first time.... In short, the Faulkner who had in 1920 lamented being born into a modern age which was "aesthetically impossible" was in 1925 beginning to discover the aesthetic possibilities of modernism. He began to sense that being born out of his time was his problem, not the age's. ("Cubist," pp. 74-75)

This digression into Faulkner's romanticism explains the mysterious woman in white ("her white dress swift in the moonlight, carrying her somewhere," p. 869) in "Mistral," who apparently is the priest's ward and is the cause of his damnation for, as Charles C. Clark posits, adultery, incest, and murder. ${ }^{8}$ Clark explains that it is adultery because the priest has "looked" (i.e. lusted) after the girl, incest because the waif is dependent on the "padre," and murder because the priest poisoned the fiancé.

Faulkner's treatment of loss in "Mistral" is especially interesting because the story was written about the time of the composition of The Sound and the Fury; in fact, in the story is a refrain that seems a forerunner of the book's title: ". . . hollowed murmurous out of chaos and the long fury of time" [italics mine] (p. 862). After seeing the girl in white, the narrator, in his interior monologue, is curiously reminiscent of Quentin's ruminations over the loss of his sister Caddy. Stylistically, the cadence seems remarkably similar to some of the prose in The Sound and the Fury, in addition to the device of repeating key words:

... losing her when she would be lost because it moved when she moved and went with her to the instant of loss. I remember how, when I learned about Thaw and White and Evelyn Nesbitt [a famous murder case in the 1920s], how I cried. I cried because Evelyn, who was a word, was beautiful and lost or I would never have heard of her. Because she had to be lost for me to find her and I had to find her to lose her. . . . I cried, because I had lost myself then and I could never again be hurt by loss. (p. 869)

Though the setting and the narrative framework of "Mistral" and The Sound and the Fury vary, many other connections pertaining to characters, theme, and style seem present. Again, one is taken by the idea that stories such as "Mistral" were the proving grounds for a work as explosive as The Sound and 
the Fury. Faulkner lends credence to the association when he reveals that the "book which took the most agony was The Sound and the Fury. Took me five years of re-working and re-writing. Never did finish it" (Lion in the Garden, p. 222). And what was Faulkner doing also in the five years between 1924 and 1929? Part of the time, at least, he was working on his stories.

\section{Part II}

The story "Snow" has received practically no critical examination since its creation. No one seems to pay it much attention: Faulkner's editors castigated it as "obscure and too complex," it was rejected several times, and finally Faulkner himself admitted that it just was "not too good." But because of Faulkner's pre-eminence in modern letters, everything he wrote (especially completed manuscripts such as "Snow") assumes a significancethe smaller compositions are the building blocks in the grander structure of his novels. By resolving the question of the date of the story's original composition, some valuable insights may be perceived about the genesis and development of The Sound and the Fury.

As previously mentioned, the first ascertainable date for "Snow" is 1942. However, if its composition date could be determined as fifteen years earlier (because the narrator of the story remarks that the events the story describes occurred fifteen years before the "present"), then it and "Mistral" could be looked upon as a fairly substantial body of text that prefaced the later novels. There is a problem, however-there isn't any firm, dated evidence yet to assign an initial writing date of 1927 or thereabouts to the story. But, this thus far somewhat arbitrary dating can be supported.

Two observations by Blotner imply an appearance earlier than 1942. The first is that, "more often than not, he [Faulkner] tended to set his stories at approximately the time he was composing them" (Faulkner, p. 595). And the second, "that Faulkner may well have thought of the present story of love and death in the Alps as early as the time of "Mistral," perhaps even written it" (Uncollected, p. 712). If the main characters in both stories are Don and the "I" narrator, if both stories have an Alpine setting, and if both concern love and murder, then may a conjecture be made that they were written at approximately the same time? That they were is a distinct possiblity.

Max Putzel supports Blotner through his investigation into a corresponding crux - the processes leading to the genesis of Sartoris. ${ }^{9}$ Working from some of Faulkner's papers at the Alderman Library at the University of Virginia, Putzel notes that the author:

developed ... first a set of personae capable of articulating his vision of mankind, next a series of incidents to give them play, and lastly a climate and locale to project their feelings and place them in the natural world. (p. 48)

He continues by remarking that: 
Faulkner kept on hand many unsold works, including the unfinished and canceled drafts of early stories. Some he reworked. Some came out years later in collections or magazines or under separate imprint. Others he drew upon in later published novels. (p. 49)

There is another body of evidence that pertains to internal parallels between the stories and the novels. Faulkner wrote the Appendix to The Sound and the Fury in October 1945, and because of the topical significance of the image, Caddy is last seen in the novel with a Nazi officer. In "Snow," as well, the femme is again associated with an offizier; however, the woman has been accused of murdering the Nazi (an interesting speculation might be initiated here: because Caddy is no longer heard from after the occasion with the officer, she may have killed him and subsequently "disappeared"this sort of continuation happens all the time to Faulkner's characters, the most famous perhaps is Flem Snopes's perpetuation from "Barn Burning" to The Hamlet). Just as the Appendix is a later addition, might not the preface and conclusion (a kind of "frame") of "Snow" about a woman and a German, and incidentally told in third person while the fifteen-year-old narrative is in first, be a later addition in an effort by Faulkner to contemporize a much older story?

A final appeal for an early dating of "Snow" revolves around the detective work of Don and the narrator. Frankly, Faulkner's unraveling of the plot to present the motive for the deaths that happen in the story isn't as adroitly handled as in other works. It seems odd that after his masterful raveling and unraveling of his characters' motives in Light in August, The Sound and the Fury, and Absalom, Absalom! that Faulkner couldn't do a more convincing job with "Snow." He worked with the story, too; it simply wasn't written, then dashed into the mail. Faulkner says as much in a 1942 letter to Harold Ober: "You had this ["Snow"] before. It is rewritten, simplified, still an implied story as before, but I have tried to fill the gaps, etc. and make it explicit as well." 10 By 1936, Faulkner was a virtuoso in planned complexity. Yet, how could a story written in late 1941 -early 1942 be faulted for, as Frank Catrell states, "complexities ... such as to make it either virtually incomprehensible or incredible. This is the principal weakness of the tale." Faulkner's letter to Ober about "Snow," he left for Hollywood to resume his screenwriting activities, which he did because the money was good. His actions during this time suggest that he resurrected "Snow" and rewrote some parts of it with the hope of making some quick cash. In all likelihood then, it is an earlier story.

The story line of "Snow" isn't too difficult to trace. A father is home on leave from the war and reading the papers when his daughter asks, "... what was Europe like before all the people in it began to hate and fear Germans?" (p. 665). The father doesn't answer because he is absorbed by a photo in the paper of a Nazi officer and a woman. The caption and brief story state that the woman-a "Frenchwoman"- stabbed to death the Nazi. 
The father thinks aloud when he says, "Except she wasn't French. ... She was Swiss" (p. 666). Then the story shifts to the first person, and the scene is fifteen years earlier in the Swiss Alps with two Americans (Don and "I") taking turns looking through a spyglass across the valley at a small party on foot carrying a body away from the site of a climbing accident. The Americans head for the same village to which the rescue team is going because it's late in the day and the youths will need a place for the night. As takes place in "Mistral," Don and the narrator, upon entering the village, make for the church and watch the funeral service. By this time Don has surmised that the man killed in the climbing mishap "didn't fall. . . . Maybe a friend pushed him. Maybe he jumped off on a bet” (p. 668). Don then accosts a man whom he mistakes for a postman, but who is actually the mayor of the village, and is told that the dead man was a local professional guide and husband to the woman in Parisian hat and coat who had just left the church. The youths leave the church to find the village inn.

At the inn, their waiter (who speaks English well, so well that he knows Chicago slang) contributes more specifics to the circumstances of the guide's death. The guide's name was Brix. He and his wife, along with another guide Emil Hiller, and a regular, wealthy client undertook a climb at the client's insistence, though Brix and his wife had been only one day into their honeymoon. The climb was to have been relatively easy and safe, but something went wrong, and the "Big Shot" client, as the waiter labels him, slipped and carried over a precipice with him Brix and the woman. Hiller had anchored his end of the line, but it would have been impossible for him to pull up the other three climbers. Brix, who dangled at the end of the line, cut himself loose and fell, thus giving Hiller a chance to pull the woman and client to safety. Brix's body wouldn't be recovered until the spring thaw. Mysteriously, Brix's one-day widow left town with the Big Shot, who was a German. The waiter ends his narrative saying- "We don't like Germans in this country" (p. 675).

The next day the two Americans leave the village by train. The events and persons involved with Brix's death prompt Don to state, "I dont want any more snow forever. I dont want to see any snow for a long time" (p. 677). The narrative then shifts back to the third person "present" with the father telling his daugher that "people in Europe have hated and feared Germans for so long that nobody remembers how it was" (p. 677).

The most immediate similarity between "Snow" and other works is Faulkner's use of the elemental metaphor; in this case it is again cold, and especially snow, that signifies a growing, encompassing evil. The imagery Faulkner displays here is particularly fine:

... the train moving ... faster still as it crashed into the blackness of the tunnel which after the snow was like a blow across the eyes and then crashed from blackness into fierce light like another blow. (p. 676) 
And in many of Faulkner's novels in which dread and evil are themes, a woman seems to precipitate the chain of events that culminates in death: there is Caddy in The Sound and the Fury, Joanna Burden and Lena Grove in Light in August, and Rosa Coldfield, Judith Sutpen, and Melicent Jones in Absalom, Absalom! The enigmatic woman in "Snow" who dresses in Parisian clothes holds a comparable position. These femmes fatales have already been shown to be products of Faulkner's romantic inheritance, and perhaps the woman in "Snow" represents a midway point between the women of The Marble Faun and The Hamlet.

The male protagonists in "Snow" seem uncannily like Shreve and Quentin in Absalom, Absalom! Both Don and Shreve are inquisitive, excitable, and slightly domineering; on the other hand, the "I" narrator and Quentin seem passive, contemplative, and melancholic. Even the physical dimensions of Don and Shreve seem comparable: Don is "about the shape of a grain elevator and almost as big" (p. 666), while Shreve is "huge and shapeless like a disheveled bear" (p. 293). Admittedly, just because two characters are big doesn't mean they are the same person with different names; however, when the personalities of these two characters are juxtaposed, it seems apparent that Don is a prototype for Shreve.

Finally, the narrative technique in "Snow" is the same as in "Mistral." Information about the main sequence of the action is given second-hand by secondary characters, and from their bits and pieces of fact, gossip, and speculation, the main characters reconstruct the events (in both stories one of these secondary characters is a waiter). Faulkner's use of implication in the stories directly forecasts his extensive application of the technique in Light in August and Absalom, Absalom!, and is the hallmark in most of his later fiction.

"Snow" is a relatively minor work seen in relation to Faulkner's novels, but as Cantrell points out, "it remains an interesting work because of both its psychological involvement and its well-developed metaphorical pattern" (p. 330). And it is unfortunate that the story was not published during its author's lifetime, or at least not earlier than 1979, because with more critical attention it has the potential-together with "Mistral"- to provide more substance to that wonderfully mysterious time between 1925 and 1929 when Faulkner matured as a novelist.

\section{NOTES}

1 P. 60 of Panthea Reid Broughton's essay, "Faulkner's Cubist Novels," in "A Cosmos of My Own": Faulkner and Yoknapatawpha 1980, ed. Doreen Fowler and Ann J. Abadie (Jackson: University Press of Mississippi, 1981), pp. 59-94; Cleanth Brooks, William Faulkner: Toward Yoknapatawpha and Beyond (New Haven: Yale University Press, 1978); Broughton, p. 61.

2 The editions of Faulkner's novels referred to are as follows: The Sound and the Fury (New York: The Modern Library, 1956); and Absalom, Absalom! (New York: The Modern Library, 1964). 
3 Lion in the Garden: Interviews with William Faulkner 1926-1962, ed. James B. Meriwether and Michael Millgate (New York: Random House, 1968), p. 222.

4 Atlantic, Nov. 1979, pp. 67-80.

5 "Mistral" appears in Collected Stories of William Faulkner (New York: Vintage Books, 1977), p. 843.76; "Snow" is a previously unpublished work appearing for the first time in Uncollected Stories of William Faulkner, ed. Joseph Blotner (New York: Random House, 1979), pp. 665-77.

6 Cleanth Brooks, "A Note on Faulkner's Early Attempts at the Short Story," Studies in Short Fiction, X, No. 4 (1973), pp. 381-88.

7 Joseph Blotner, Faulkner: A Biography, 2 vols. (New York: Random House, 1974), p. 490.

8 P. 199 of “ 'Mistral': A Study in Human Tempering," The Mississippi Quarterly, XXI (Summer 1968), pp. 195-205.

9 Max Putzel, "Evolution of Two Characters in Faulkner's Early and Unpublished Fiction," The Southern Literary Journal, V, No. 2 (1973), pp. 47-63.

10 Selected Letters of William Faulkner, ed. Joseph Blotner (New York: Random House, 1977), p. 161.

II P. 330 of “An Unpublished Faulkner Short Story: 'Snow,' " The Mississippi Quarterly, XXVI (Summer 1973), pp. 325-30. 